\title{
Effects of gibberellic acid and sowing date on harvest time and yields of seed-grown globe artichoke (Cynara scolymus L)
}

\author{
G Mauromicale *, A lerna \\ Centro di studio sulle colture erbacee strategiche per l'ambiente mediterraneo del CNR, \\ Istituto di Agronomia generale e Coltivazioni erbacee, Università di Catania, Via Valdisavoia 5, I-95123 Catania, Italy
}

(Received 17 May 1995; accepted 27 October 995)

Summary - A 2 year research project was carried out in Sicily (south Italy), in order to study the effects of gibberellic acid $\left(\mathrm{GA}_{3}\right)(0,1,2$ or 3 plant applications at $60 \mathrm{ppm})$ and sowing date (from 1 July to 10 August) on the timing of production and head yield of globe artichoke variety Orlando, a new seed-grown $F_{1}$ hybrid. Regardless of sowing date, untreated plants of Orlando produced heads the next spring, confirming that in the Mediterranean environment seed-grown varieties have to overcome the winter season or part of it to meet their cold requirement for flower initiation. $\mathrm{GA}_{3}$ application replaced this cold requirement, allowing autumnal production. $\mathrm{GA}_{3}$ effectiveness, however, was more evident in early sowings than in later ones. In fact, a combination of early sowings ( 1 and $10 \mathrm{July}$ ) and $\mathrm{GA}_{3}$ application (2 or 3 times) resulted in a pattern of head production of Orlando similar to that of Violetto di Sicilia (VS), a typical early vegetatively propagated variety. In addition, the total cumulative yield at the end of cycle was significantly higher in Orlando than in VS.

Cynara scolymus $\mathrm{L}=$ globe artichoke / seed-grown plant / sowing date / gibberellic acid / harvest time

Résumé - Influence de l'acide gibbérellique et de la date de semis sur le calendrier de production et le rendement de l'artichaut multiplié par graines. La multiplication de l'artichaut (Cynara scolymus $L$ ) par graines offre beaucoup d'avantages par rapport à la multiplication par voie végétative : diminution des frais de plantation, homogénéité du développement des plantes, garantie phytosanitaire, facilité et rapidité de diffusion des nouvelles variétés, obtention du rendement maximal des plantes dès la première année. Cependant l'introduction au champ sur une grande échelle des variétés par graines dans la zone méditerranéenne est limitée parce qu'il n'est pas possible d'obtenir la production en automne à cause des exigences en froid de ces variétés pour l'induction florale. Afin de mettre au point une technique pour la production automnale des variétés à multiplication par semences qui pourrait faciliter leur diffusion, on a étudié dans 2 localités de Sicile (Catania et Siracuse) l'influence de différentes dates de semis (du 1er juillet au 10 août) et traitements avec l'acide gibbérellique - $G A_{3}(0,1,2,3$ applications à une concentration de 60 ppm) sur le calendrier de production ainsi que sur le rendement d'Orlando, nouvelle variété à multiplication par semences. Pour toutes les dates de semis, les plantes du traitement témoin de la variété Orlando ont produit les capitules au printemps. Le traitement avec $\mathrm{GA}_{3}$ a entraîné une anticipation de la date de maturation d'autant plus élevée que l'époque de semis a été précoce; la combinaison de semis précoces (1, 10 juillet) et l'application de $\mathrm{GA}_{3}$ (2 ou 3 fois) ont permis

\footnotetext{
* Correspondence and reprints
} 
d'obtenir un calendrier de production semblable à celui du "Violetto di Sicilia» (VS), variété à multiplication végétative. En outre, les rendements en capitules cumulés à la fin de la récolte ont atteint des valeurs significativement plus élevées pour Orlando que pour VS.

Cynara scolymus $L=$ artichaut / multiplication par semences / acide gibbérellique / calendrier de production

\section{INTRODUCTION}

The globe artichoke (Cynara scolymus $L$ ) is a perennial rosette plant, native of the Mediterranean Basin. Traditionally it is propagated vegetatively by basal stem pieces (stumps) and suckers in a dormant or nondormant state. Recently, seed-grown varieties with plant uniformity have been introduced (Basnizki and Zohary, $1987,1994)$. These are mainly spring-producing varieties (Mauromicale et al, 1989; Elia et al, 1991; Mauromicale, 1994), while traditional varieties cultivated in the Mediterranean Basin like Violetto di Sicilia (VS), Violet de Provence, Blanca de España, Spinoso Sardo, start their production in autumn (Pécaut, 1993).

Globe artichokes behave like biennials, since they require low temperatures, followed by long days for flower formation and stem elongation (Basnizki, 1985; Foury, 1987; Pécaut, 1993). In the Mediterranean areas, plants are sown in summer, complete their juvenile phase before winter, and produce in the next spring. This production period counteracts the economic advantages of seed planting, such as reduction of the planting costs, easier mechanization, full production in the first year of planting, improvement of crop sanitation, and easier and quicker introduction of new varieties (Pécaut et al, 1981; Basnizki and Zohary, 1987; Foury and Pécaut, 1988; Mauromicale et al, 1989). Harvesting in autumn is, therefore, an absolute requirement to ensure a successful introduction of seed-grown varieties.

Gibberellic acid $\left(\mathrm{GA}_{3}\right)$ treatment causes earlier harvest in vegetatively propagated varieties (Marzi and Dellacecca, 1969; Snyder et al, 1971; De Malach et al, 1976; Foury, 1977; Foti and La Malfa, 1981; Mangano and Signorelli, 1981; Patourel and Foury, 1981; Foury et al, 1983). Recent research performed on seed-grown varieties indicated that $\mathrm{GA}_{3}$ effectiveness on earliness depends on sowing dates, the sensitivity of each variety to $G A_{3}$, and the number of $G_{3}$ treatments (Elia et al, 1992; Schrader, 1992; Basnizki and Goldschmidt, 1994; Mauromicale, 1994).

The purpose of this study was to evaluate the effects of different $\mathrm{GA}_{3}$ applications and sowing dates on harvest time and yield of a new seedgrown hybrid.

\section{MATERIALS AND METHODS}

\section{Localities}

Field experiments were conducted in 1990-1991 in Sicily at Siracusa $\left(36^{\circ} 58^{\prime} \mathrm{N}, 15^{\circ} 11^{\prime} \mathrm{E}, 10 \mathrm{~m}\right.$ above sea level) and in 1991-1992 at Catania $\left(37^{\circ} 27^{\prime} \mathrm{N}, 15^{\circ} 04^{\prime} \mathrm{E}\right.$, $10 \mathrm{~m}$ above sea level), which are highly representative of the areas of globe artichoke cultivation in Italy. These areas are characterized by mild winters and dry, hot summers. The mean daily temperature from December to March ranges from $10.7^{\circ} \mathrm{C}$ to $12.1^{\circ} \mathrm{C}$. Frosts are virtually absent in Siracusa (2 events in 30 years) but quite frequent (20 events in 30 years) in Catania. In both areas, temperatures above $35^{\circ} \mathrm{C}$ are encountered every year during the summer. These climates make it possible to harvest early vegetatively propagated varieties during the period autumnwinter-spring.

\section{Experimental design and $G A_{3}$ application}

The experiments were set up in randomized split-plot design with 4 replications and involved the treatments reported in table I. In 1990, sowing date was the main plot, $\mathrm{GA}_{3}$ treatment the sub-plot. In 1991, sowing or planting date was the main plot, variety the sub-plot and $\mathrm{GA}_{3}$ treatment the sub-sub-plot. To simplify the text, we will use the sowing date also as the planting date. In both years, each plot consisted of 12 plants.

Aqueous solutions of $60 \mathrm{ppm}$ of $\mathrm{GA}_{3}$ (Berelex, $\mathrm{ICl}$ Soplant) were acidified to $\mathrm{pH} 4$ by urea phosphate (Basnizki et al, 1986) and then applied early in the morning when plants were turgid. A single application was made using a hand-sprayer on leaves until runoff. According to the different plant dimensions, the spray volume was $100,300,400 \mathrm{ml}^{\text {plant }}{ }^{-1}$, when application was at the stage of the 8th, 15th and 25th expanded leaf, respectively. The first, second and third $\mathrm{GA}_{3}$ applications were made on 14 and 29 September and 14 October (sowing of 10 July 1990), on 8 and 25 October and 10 November (sowing of 10 August 1990), on 6 and 21 September and 6 October (sowing of 1 July 1991), on 21 September and 6 and 22 October (sowing of 20 July 1991) and on 20 December and 9 and 31 January (sowing of 20 August, 1991). 
Table I. Treatments under study.

\section{Sowing date}

$1990-1991$

$\begin{array}{ll}10 \text { July } & \text { Orlando } \\ 10 \text { August } & \text { Orlando }\end{array}$

1991-1992

1 July

10 August
Orlando and VS

Orlando and VS

Variety

Orlando and VS
$G A_{3}$ application

\author{
Untreated plants (control) \\ $\mathrm{GA}_{3}$ applied once at 8-leaf stage \\ $\mathrm{GA}_{3}$ applied twice at $8+15$-leaf stage \\ $\mathrm{GA}_{3}$ applied 3 times at $8+15+25$-leaf stage
}

Untreated plants (control)

$\mathrm{GA}_{3}$ applied twice at $8+15$-leaf stage

$\mathrm{GA}_{3}$ applied three times at $8+15+25$-leaf stage

\section{Plant material and management practices}

VS is the main Italian variety and is cultivated for over $70 \%$ of the total artichoke production area (Mauromicale, 1987). It is vegetatively propagated and produces head when irrigated, from October-November to May, with a peak in March-April. Hybrid Orlando (previous name HU 271) is a seed-grown variety from the Department of Evolution, Systematics and Ecology, The Hebrew University of Jerusalem, Israel, which is harvested in March-April (Basnizki, personal communication).

Crop planting by ovoli (dormant suckers) for VS and sowing by seed (achenes) for Orlando were carried out directly in the field on the same dates (table I).

\section{Data collection}

Heads (capitules) were harvested at marketing stage regardless of size. During the fall-winter harvest period (from October to February), harvesting was once a week. In the spring (from March to May) harvesting was done every 3-4 d. All heads were weighed without scape (stalk). In this work, only marketable heads were considered.

\section{Data analysis}

Results were analyzed by ANOVA and means compared by the LSD test, provided the $F$ test was significant. A separate analysis was conducted for each sowing date. Only the data of cumulative yield at end of harvest were analyzed including sowing dates.

\section{RESULTS}

\section{Harvest time}

The combination between early sowings and appropriate treatments with $\mathrm{GA}_{3}$ was able to modify substantially the harvest period of seedgrown Orlando $F_{1}$. The effectiveness of $\mathrm{GA}_{3}$ proved greater with an earlier sowing date.

\section{Siracusa 1990-1991}

The harvest of untreated plants from the first and the second sowing date started on 11 and 22 March, respectively, and continued until 16 April. From the 10 July sowing, plants treated with $\mathrm{GA}_{3}$ began to produce on 31 October ( $113 \mathrm{~d}$ after sowing) and continued until 16 April regardless of the number of applications (fig 1). From the 10 August sowing, in contrast, the beginning of the harvest was correlated with the number of $\mathrm{GA}_{3}$ applications. $A$ single $\mathrm{GA}_{3}$ application enabled harvesting on 12 March, while, 2 or 3 consecutive applications caused the start of harvest as early as 5 January, $66 \mathrm{~d}$ before (fig 1).

\section{Catania 1991-1992}

In this trial, the response of hybrid Orlando to $\mathrm{GA}_{3}$ and sowing date was substantially similar to that of the Siracusa trial. The harvest of $\mathrm{GA}_{3}$ - 
SIRACUSA (1990 - 1991)

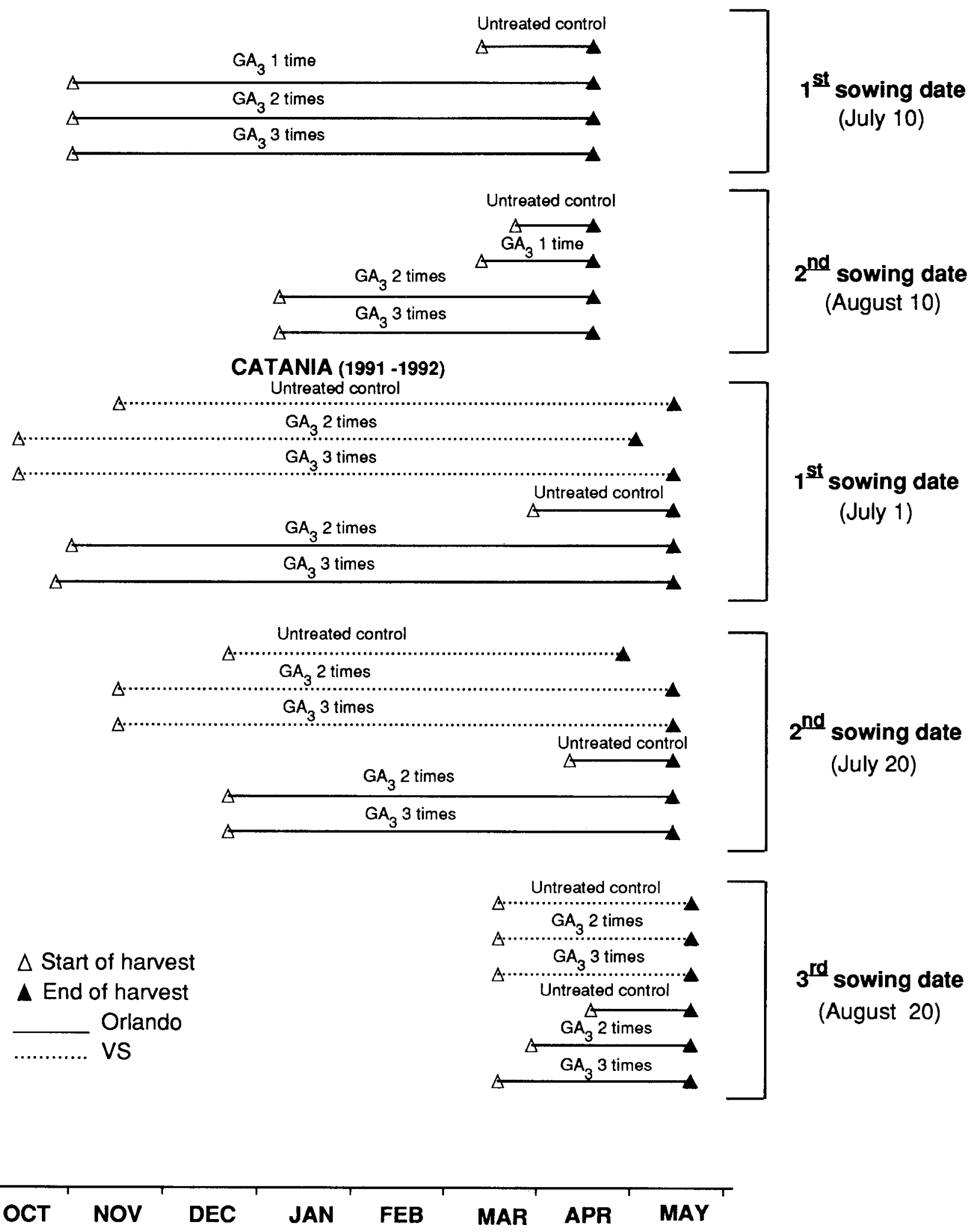

Fig 1. Effects of sowing dates and $\mathrm{GA}_{3}$ treatments on the harvest period. 
treated Orlando sown on 1 July started at the end of October. This is about 2 weeks later than vegetatively propagated VS with $\mathrm{GA}_{3}$ treatments and 2 weeks earlier than VS without $G_{3}$. Sowing on 20 July delayed the start of harvest until 20 December in $\mathrm{GA}_{3}$-treated Orlando and in untreated plants of VS. When sowing was only on 10 August, the harvest of $\mathrm{GA}_{3}$-treated Orlando began on 17 March after 3 applications and on 28 March after 2 applications. This is only one month before untreated plants, and is contemporary with $\mathrm{GA}_{3}$-treated or untreated plants of VS (fig 1).

In other words, delay in sowing from 1 July to 10 August retarded harvests of $\mathrm{GA}_{3}$-treated Orlando or VS by 5 months (fig 1).

\section{Monthly yield accumulation and cumulative yield at the end of harvest}

In both trials, sowing dates and $\mathrm{GA}_{3}$ also significantly affected the monthly harvests and yields, either in number or weight of heads per plant.

\section{Siracusa 1990-1991}

On both sowing dates, the increase in the number of $\mathrm{GA}_{3}$ applications (from 1 to 3 applications) resulted in a significant increase in head production during the autumn and winter (figs 2 and 3 ). On 31 December (still a profitable marketable date for production in Mediterranean areas) plants sown on 10 July and treated 3 times with $\mathrm{GA}_{3}$, produced 2.4 heads corresponding to $0.333 \mathrm{~kg} \mathrm{plant}^{-1}$. This is an increase of $104 \%$ in number and $134 \%$ in weight compared with the production of plants which received $2 \mathrm{GA}_{3}$ applications, and of 443 and $324 \%$ compared with those with $1 \mathrm{GA}_{3}$ application. On 31 March, differences due to the different numbers of $\mathrm{GA}_{3}$ applications were even more remarkable: 6.8 heads plant ${ }^{-1}$ corresponding to $0.940 \mathrm{~kg} \mathrm{plant}^{-1}$ with $3 \mathrm{GA}_{3}$ applications, 2.4 heads plant ${ }^{-1}$ $\left(0.303 \mathrm{~kg} \mathrm{plant}{ }^{-1}\right)$ with 2 applications, and 0.75 heads plant $^{-1}\left(0.135 \mathrm{~kg} \mathrm{plant}^{-1}\right)$ with 1 application.

Untreated plants produced only 0.62 heads plant ${ }^{-1}$ (0.082 kg plant $\left.{ }^{-1}\right)$ until 31 March (figs 2 and 3 ).

Regarding the 10 August sowing, only repeated applications of $\mathrm{GA}_{3}$ were effective. Three applications significantly increased yields obtained in February and March in comparison to 2 applications (figs 2 and 3 ). Plants with a single application of $\mathrm{GA}_{3}$ and the untreated control produced approximately $97 \%$ of the total yield (in number or in weight) only in April.

The delay of sowing from 10 July to 10 August weakened $\mathrm{GA}_{3}$ effect on early yield. From the first sowing, 3 applications of $\mathrm{GA}_{3}$ resulted in a harvest of 2.4 heads plant ${ }^{-1}\left(0.333 \mathrm{~kg} \mathrm{plant}^{-1}\right)$ at the end of December. From the second sowing, the yield reached approximately the same level only at the end of February (figs 2 and 3 ).

In both sowings, $\mathrm{GA}_{3}$ had opposite effects on cumulative yield at the end of harvest (fig 4). In the first sowing, 1 or $2 \mathrm{GA}_{3}$ treatments reduced the yield significantly in comparison to control (untreated plants) but 3 applications did not. However, in the second sowing, $\mathrm{GA}_{3}$ treatments significantly increased yield (fig 4).

\section{Catania 1991-1992}

For the 1 July sowing, during the period October-January, in $\mathrm{GA}_{3}$-treated Orlando (regardless of the number of applications), the yield (in number or in weight of heads) was similar to that of $\mathrm{GA}_{3}$-treated VS, and significantly higher than untreated VS (figs 5 and 6). During the period February-March, the yield of Orlando treated 3 times was higher than that of the plants which received 2 treatments and not significantly different from that of treated or untreated VS. Untreated Orlando produced 1, 87 and $12 \%$ of heads (in number or in weight) at the end of March, and in April and May, respectively.

The yield of $\mathrm{GA}_{3}$-treated Orlando from the July 20 sowing (regardless of number of applications) was significantly lower during NovemberJanuary, than that of $\mathrm{GA}_{3}$-treated VS, but it was not different from that of untreated VS (figs 5 and 6). During March, the yield of Orlando treated 3 times increased considerably to 5.8 heads plant $^{-1}\left(0.924 \mathrm{~kg} \mathrm{plant}^{-1}\right)$, significantly overcoming yields of VS treated or untreated plants. Untreated plants of Orlando yielded 81 and 19\% of their heads in April and May, respectively (figs 5 and 6).

Treatment with $\mathrm{GA}_{3}$ was less effective in the August 10 sowing, where there was a spring harvest only. In both varieties, $\mathrm{GA}_{3}$ allowed a generally higher rate of head production at an earlier date: March-April instead of May compared with the control. However, Orlando with $3 \mathrm{GA}_{3}$ applications exhibited a higher yield during April and May (figs 5 and 6 ).

Total yield cumulated at the end of the harvest was significantly higher for the third than for the 

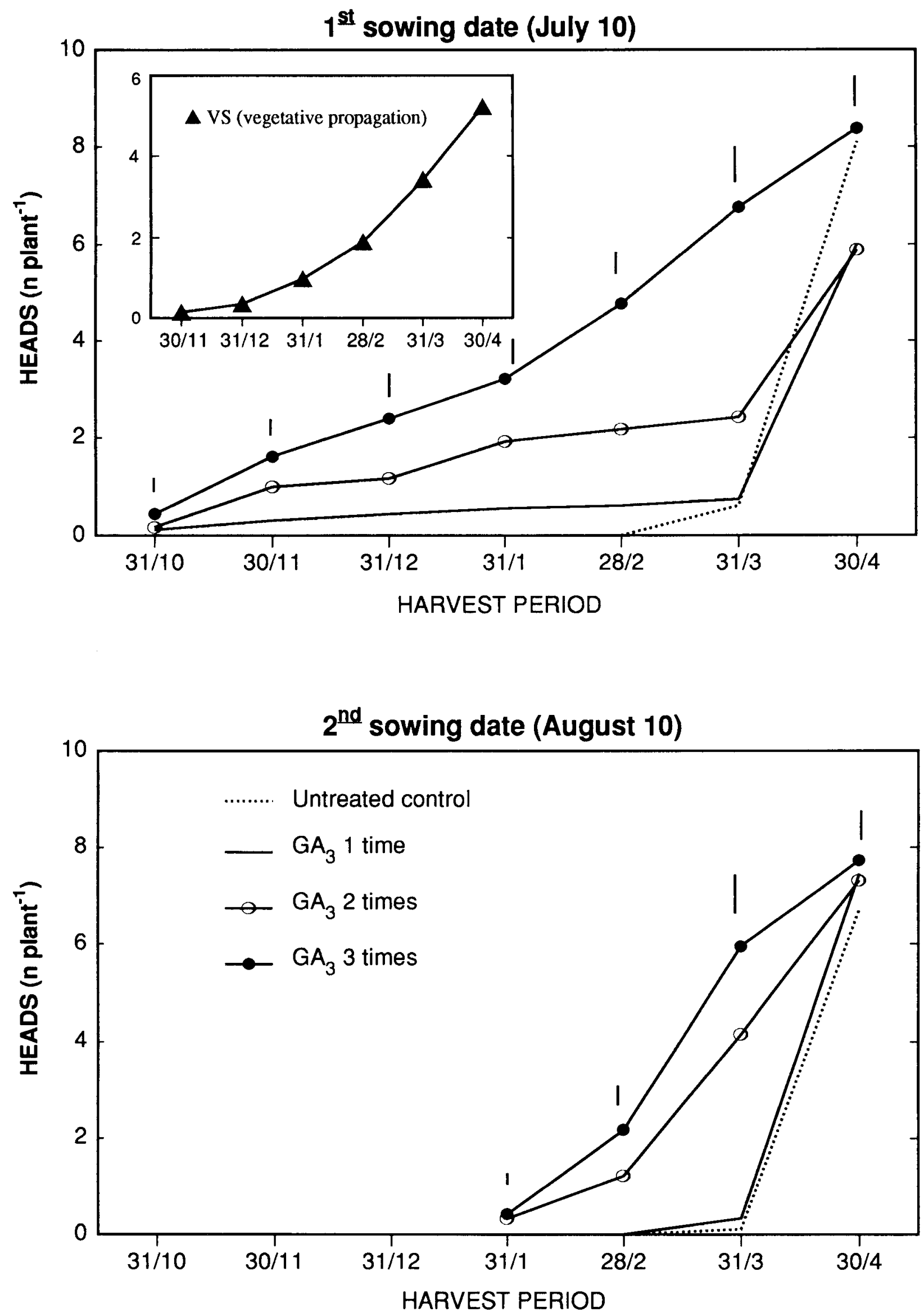

Fig 2. Siracusa, 1990-1991. Effects of sowing dates and $\mathrm{GA}_{3}$ treatments on monthly number of heads accumulation of seed-grown variety Orlando. The vertical scale bar indicates LSD $(P \leq 0.05)$. The inset shows an usual production pattern of the vegetatively propagated variety VS. 

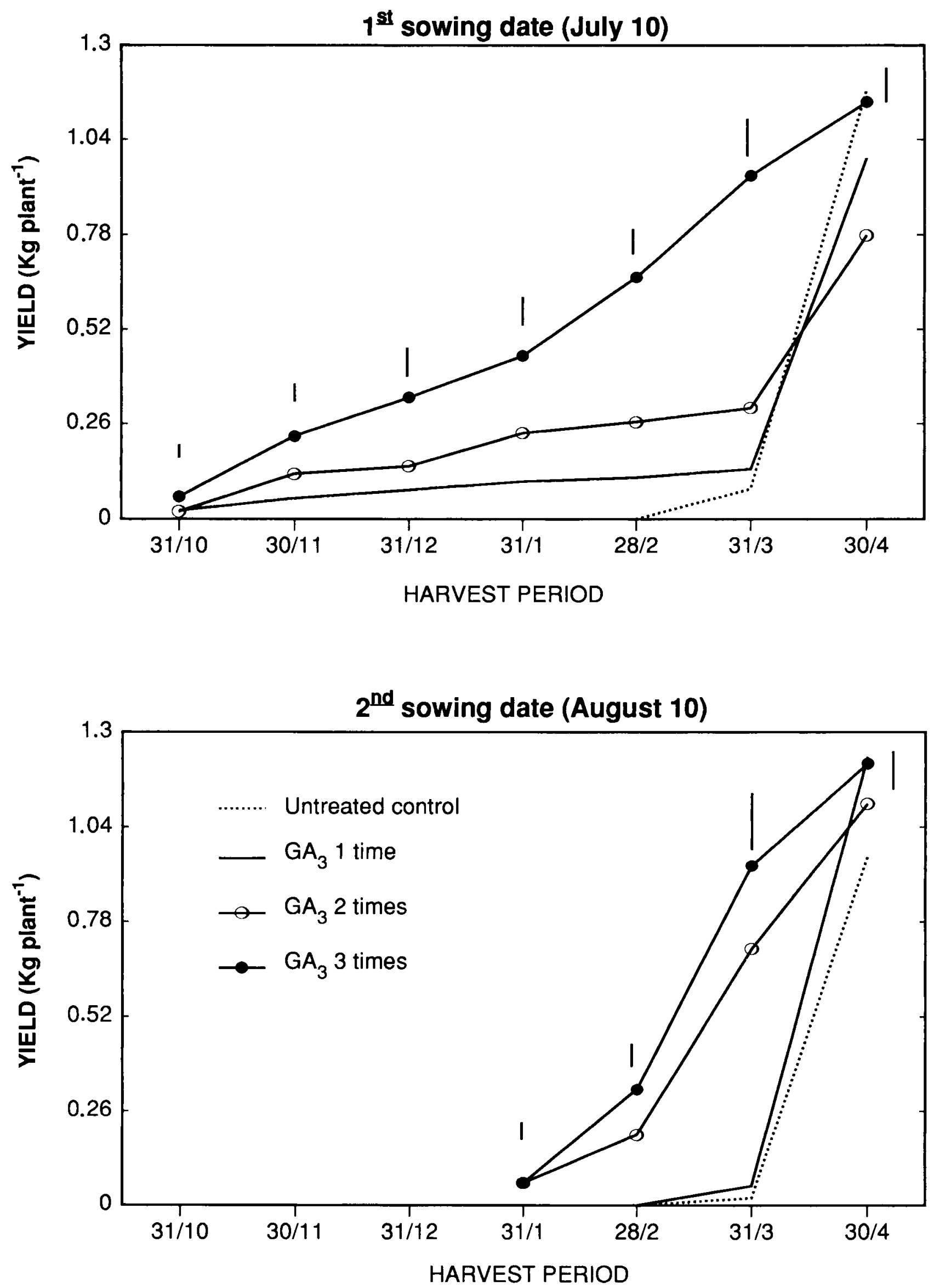

Fig 3. Siracusa, 1990-1991. Effects of sowing dates and $\mathrm{GA}_{3}$ treatments on monthly heads yield accumulation of seed-grown variety Orlando. The vertical scale bar indicates LSD $(P \leq 0.05)$. 


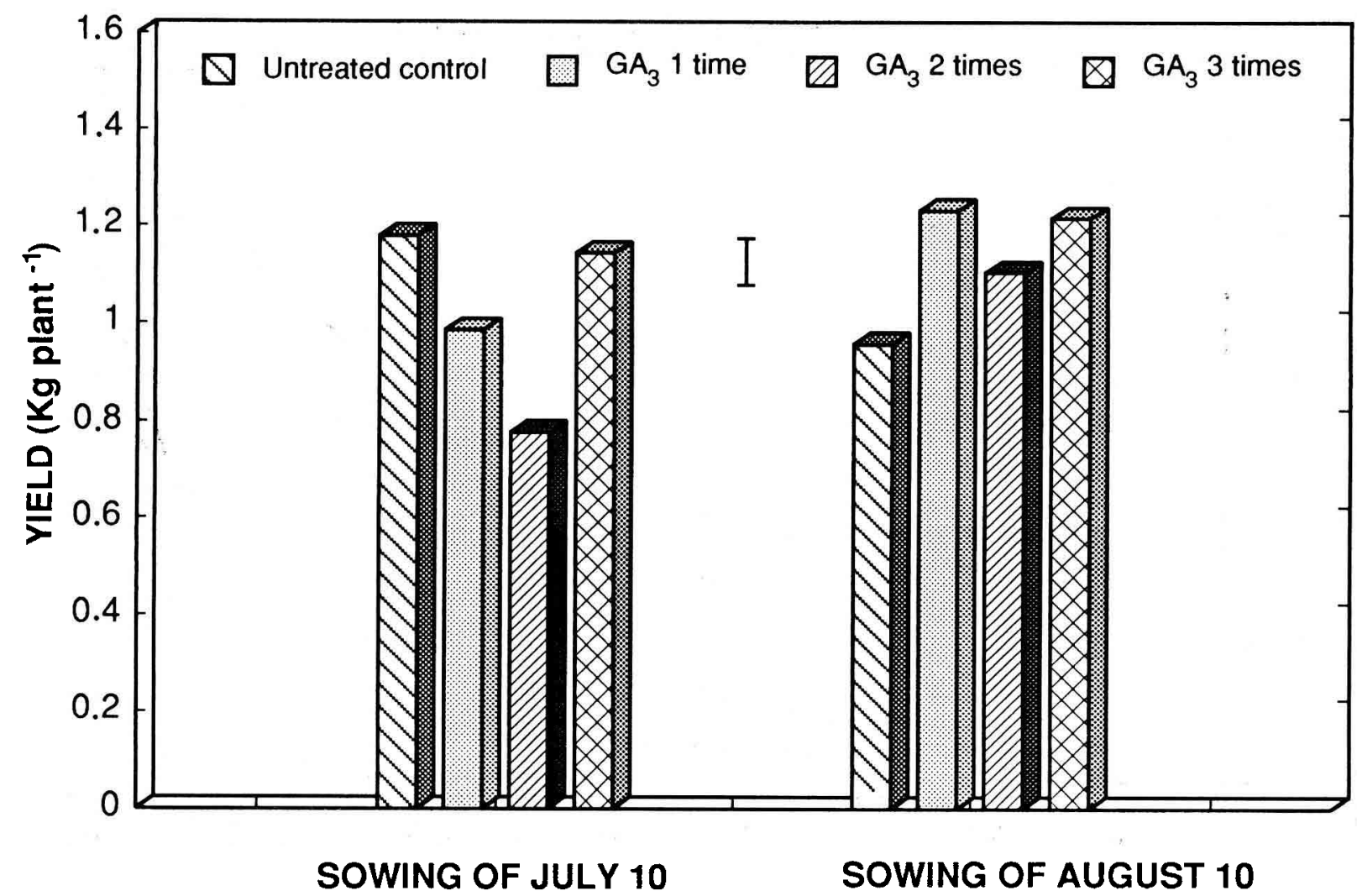

Fig 4. Siracusa, 1990-1991. Effects of sowing date $x$ number of $\mathrm{GA}_{3}$ treatments on cumulative heads yield of Orlando at the end of harvest. The vertical scale bar indicates LSD $(P \leq 0.05)$.

second and for the second than for the first sowing date, for Orlando than for VS, and for plants treated 3 times with $\mathrm{GA}_{3}$ or untreated than for the plants treated twice (fig 7). No significant interactions between the factors studied were detected.

\section{Some observations}

Plant homogeneity and vigour of Orlando were satisfactory and always higher than VS values.

$\mathrm{GA}_{3}$ application increased plant vigour more in Orlando than in VS and it did not influence the marketable fitness of the heads.

Head characteristics (weight, shape, dimensions and scape height) were significantly influenced by variety, sowing date, $\mathrm{GA}_{3}$ treatment and maturation date. We are still working on these results to present them in a future paper in this journal.

\section{DISCUSSION AND CONCLUSIONS}

The results of this research confirm that in the Mediterranean environment seed-grown varieties have to be subjected to the winter season or part of it to produce heads, but they also demonstrate that it is possible to obtain autumn production by combining sowing dates with $\mathrm{GA}_{3}$ treatments. The correct combination between sowing date and $\mathrm{GA}_{3}$ enabled uninterrupted harvesting of seed-grown Orlando from end of October to midMay. The monthly productions were similar to those of VS.

For autumn harvesting, it is necessary to sow Orlando not later than 10 July and to apply 2 or 3 consecutive $\mathrm{GA}_{3}$ treatments. In the Catania trial, sowing on 20 July and applying $\mathrm{GA}_{3} 2$ or 3 times allowed a production starting in winter, almost at the same time and with the same monthly production as at Siracusa with sowing on 10 August. The longer duration from sowing to the beginning of the harvest at Catania in comparison to Siracusa is probably due to a slow plant growth during October-December as a result of lower mean minimum or maximum temperatures by 2.5 or $1.5^{\circ} \mathrm{C}$, respectively.

The negative effect of late sowing on the earliness was evident when sowing was only on 10 August. In this case, harvesting of $\mathrm{GA}_{3}$-treated plants was delayed until the early spring. 

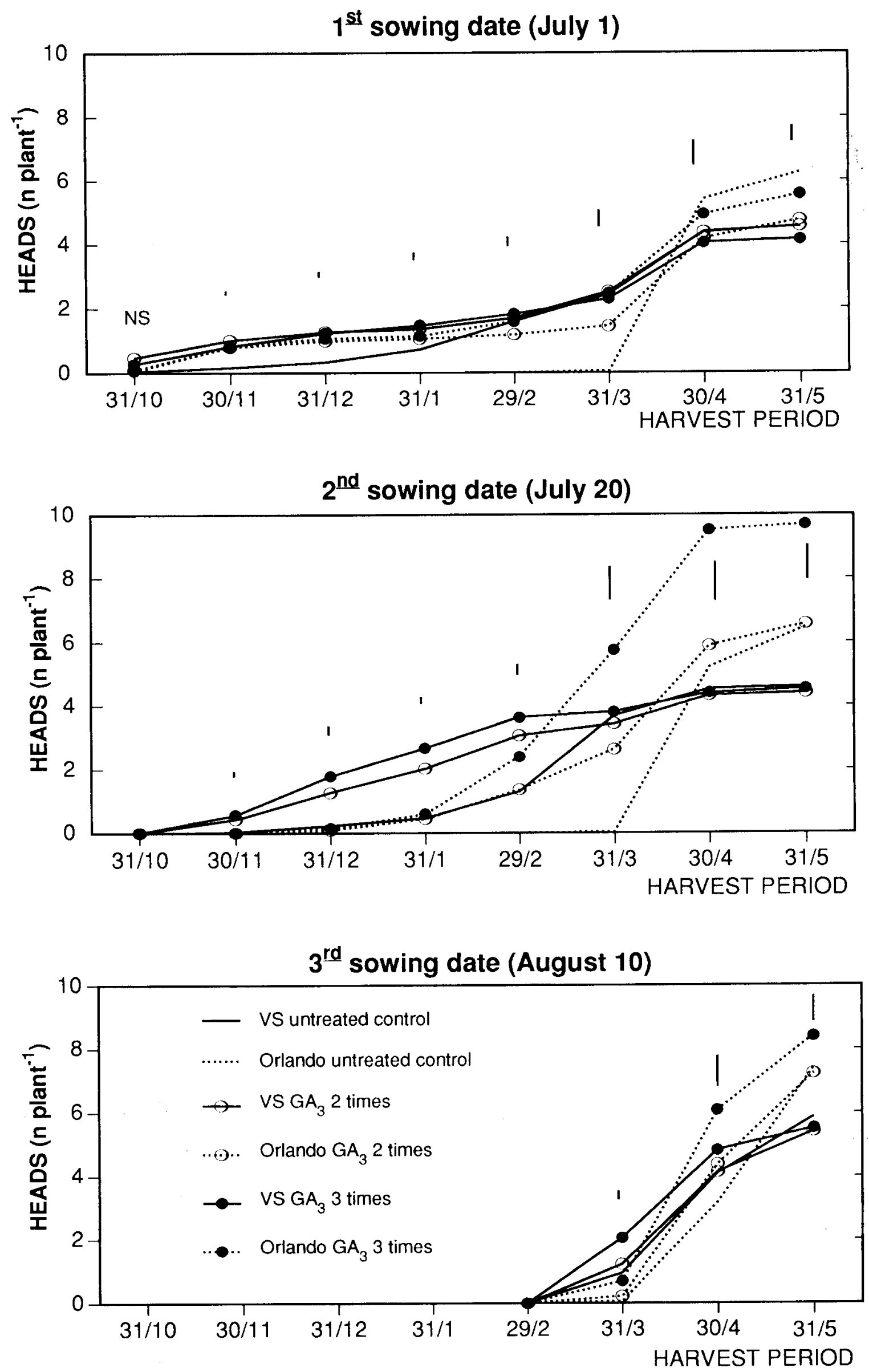

Fig 5. Catania, 1991-1992. Effects of sowing dates and $\mathrm{GA}_{3}$ treatments on monthly number of heads accumulation of seed-grown variety Orlando and vegetatively propagated variety VS. The vertical scale bar indicates LSD $(P \leq 0.05)$. 

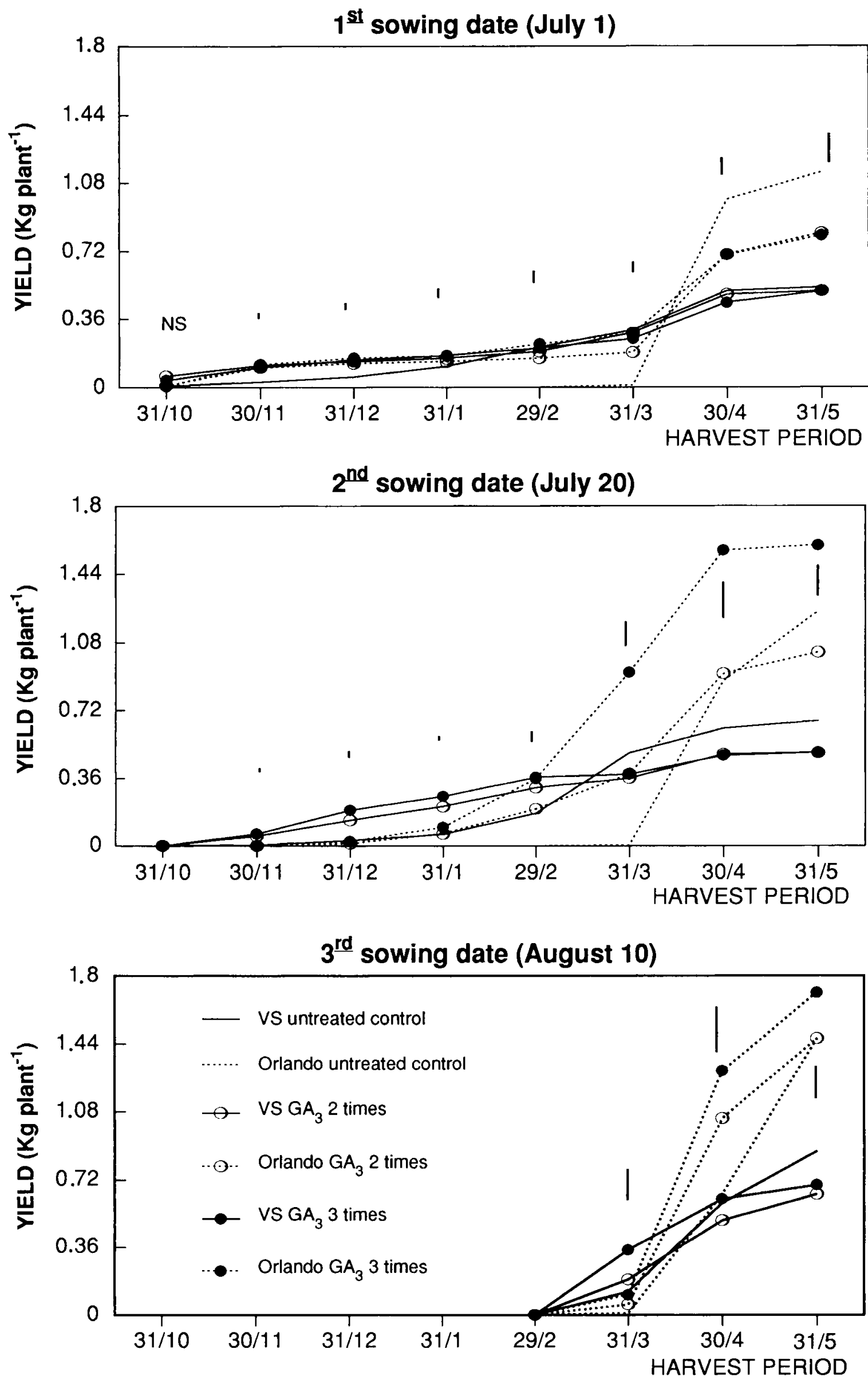

Fig 6. Catania 1991-1992. Effects of sowing dates and $\mathrm{GA}_{3}$ treatments on monthly heads yield accumulation of seed-grown variety Orlando and vegetatively propagated variety VS. The vertical scale bar indicates LSD $(P \leq 0.05)$ 


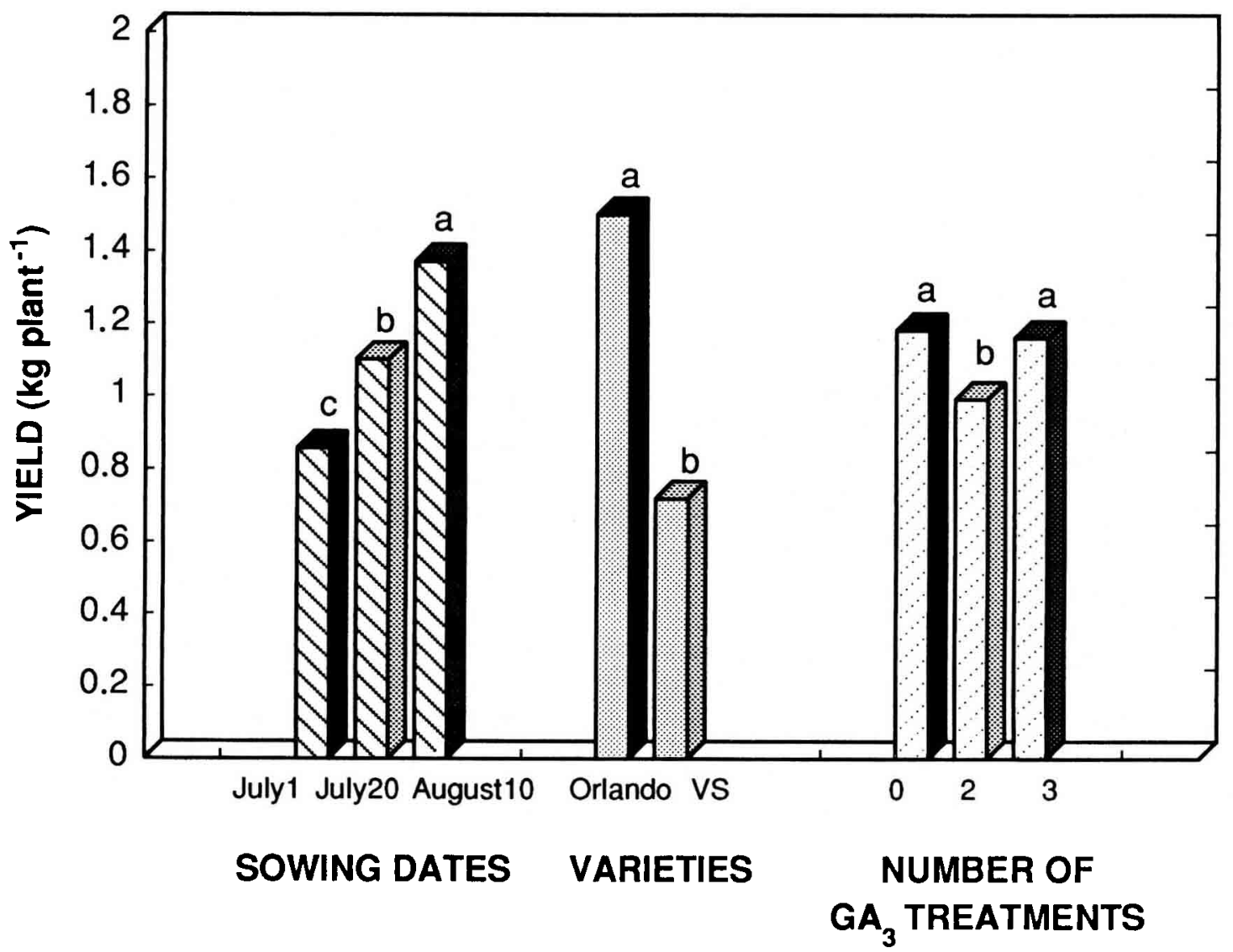

Fig 7. Catania, 1991-1992. Effects of sowing dates, number of $\mathrm{GA}_{3}$ treatments and varieties on cumulative heads yield at the end of harvest. Yield, within a single factor, with different letters are significantly different $(P \leq 0.05)$.

The results reported here contribute to knowledge on the possibility of exogenous $\mathrm{GA}_{3}$ to stimulate flowering in the seed-grown globe artichoke. The floral induction of seed-grown plants requires a chilling of about $250 \mathrm{~h}$ at temperatures below $7^{\circ} \mathrm{C}$ (Foury and Pecaut, 1988). At high temperatures $\left(\geq 18^{\circ} \mathrm{C}\right)$, in fact, plants grown under different day lengths ( 8 and $16 \mathrm{~h}$ light) remain vegetative (Basnizki, 1985; Basnizki and Goldschmidt, 1994). In the first seed-grown varieties, manipulations like seed vernalization, $\mathrm{GA}_{3}$ treatments and different sowing dates were unable to replace cold requirements for autumnal harvest (Foury and La Malfa, 1976; Mauromicale, 1994). The present study has demonstrated, on the contrary, that exogenous $\mathrm{GA}_{3}$ applications can replace cold requirements in Orlando, which is a genetically improved variety.

\section{REFERENCES}

Basnizki Y (1985) Cynara scolymus. In: Handbook of Flowering (AH Halevy, ed), vol 2, CRC Press, Boca Raton, FL, 391-399
Basnizki Y, Goldschmidt EE (1994) Further examination of gibberellin $A_{3}$ effects on flowering of globe artichokes (Cynara scolymus L) under controlled environment and field conditions. Isr J Plant Sci 42 , 159-166

Basnizki Y, Zohary D (1987) A seed-planted cultivar of globe artichoke. HortScience 22, 678-679

Basnizky Y, Zohary D (1994) Breeding of seed-planted artichoke. Plant Breed Rev 12, 253-269

Basnizki $Y$, Goldschmidt E, Luria $Y$, Itach $H$, Berg Z, Galili D (1986) Effect of acidified $\mathrm{GA}_{3}$-spray on yield of globe artichoke (Cynara scolymus L). Hasadeh 66, 1814-1817 (in Hebrew, English summary)

De Malach JG (De Angelis), Sachs M, Rotem R (1976) Timing and optimal concentration of gibberellic acid treatments for forcing yield of globe artichoke (Cynara scolymus L). In: Atti $2^{\circ}$ Congr Int Carciofo, Bari, Minerva Medica, Turin, Italy, 633-642

Elia A, Paolicelli F, Bianco VV (1991) Effect of sowing date, plant density and nitrogen fertilizer on artichoke (Cynara scolymus $L$ ): preliminary results. $A d v$ Hort Sci 3, 119-122

Elia A, Calabrese N, Losavio PP, Manolio G (1992) Epoche di semina e produzione di quattro cultivar di carciofo propagate per seme. In: Atti Giornate Scientifiche, Soc Ort Ital, Ravello, Italy, 250-251 
Foti S, La Malfa G (1981) Influenza di fattori termici, luminosi e chimici sulla emissione del capolino in Cynara scolymus L. In: Atti $3^{\circ}$ Congr Int Carciofo, Bari, Laterza, Bari, Italy, 207-217

Foury C (1977) Essai d'application d'acide gibbérellique $\mathrm{GA}_{3}$ sur une culture d'artichaut de printemps (Cynara scolymus L) cultivar «Blanc Hyérois». Ann Amélior Plant 27, 411-426

Foury C (1987) Quelques aspects du développement de l'artichaut (Cynara scolymus L) issu de semences ; analyse plus particulière de la floraison en conditions naturelles. Thèse, Univ P-et-M-Curie, Paris-VI, France

Foury C, La Malfa G (1976) Risultati di ricerche sull'accrescimento e sullo sviluppo di piante da seme di linee di carciofo di una nuova costituzione coltivate in ambienti diversi. In: Atti $2^{\circ}$ Congr Int Carciofo, Bari, Minerva Medica, Turin, Italy, 329-341

Foury C, Pecaut P (1988) Quelques aspects du développement de l'artichaut (Cynara scolymus $\mathrm{L}$ ) : problèmes posés par la substitution de la reproduction sexuée à la multiplication végétative. $C R$ Acad Agric Fr 74, 85-92

Foury C, Moulin JC, Martin F (1983) Possibilités d'utilisation de la gibbérelline pour hâter la récolte d'artichaut en régions méridionales. PHM - Revue Hort 234, 49-54

Mangano G, Signorelli P (1981) Azione di trattamenti con acido gibberellico, in fasi diverse dell'accrescimento delle piante, sulla produzione del carciofo. In: Atti $3^{\circ}$ Congr int Carciofo, Bari, Laterza, Bari, Italy, 565-579
Marzi V, Dellacecca V (1969) Influenza dell'acido gibberellico sull'anticipo di produzione del carciofo. Scienza e Tecnica Agraria 8, 201-215

Mauromicale G (1987) Panorama varietale del carciofo e sua prevedibile evoluzione. L'Inf Agr 43, 69-75

Mauromicale G (1994) Influenza del genotipo e dell'ambiente sul calendario di produzione del carciofo propagato per 'seme'. L'Inf Agr 50, 61-65

Mauromicale G, Basnizki Y, Cavallaro V (1989) Primi risultati sperimentali sulla propagazione del carciofo (Cynara scolymus L) per seme. Riv di Agron 23, 417-423

Patourel L, Foury C (1982) Quelques effets de la gibberelline sur l'artichaut : intérêt pour les cultures traditionnelles. Bull Tech Inform 369, 273 285

Pecaut P (1993) Globe artichoke Cynara scolymus L. In: Genetic Improvement of Vegetable Crops (G Kalloo, BO Bergh, eds), Pergamon Press, Oxford, 737-745

Pecaut P, Foury C, Rico F, Martin F (1981) Bilan d'un premier cycle de sélection de variétés d'artichaut à semer. In: Atti $3^{\circ}$ Congr Int Carciofo, Bari, Laterza, Bari, Italy, 615-627

Schrader WL (1992) Growth regulator effects on earliness and yield in artichokes grown as annuals from seed. HortScience 27, 643 (Abstr)

Snyder MJ, Welch NC, Rubatzky VE (1971) Influence of gibberellin on time of bud development in globe artichoke. HortScience 6, 484-485 